\title{
Interest Arbitration - A Case Study Lancaster Police Benevolent Association And The Town of Lancaster
}

John G. Watson (E-mail: jwatson@ @bu.edu), St. Bonaventure University

\begin{abstract}
Arbitration is a process wherein a dispute is submitted to an impartial third party for a binding decision. Interest Arbitration involves a dispute over the terms of a proposed collective bargaining agreement. In an Interest Arbitration an impartial third party renders a binding decision on the terms of the collection bargaining agreement. The case study describes a situation where the Lancaster Police Benevolent Association (Union) is negotiating a collective bargaining agreement with the Town of Lancaster. As the parties were unable to resolve the contract through negotiations, an impasse was declared. A demand for arbitration was made by the Union, and the matter was ultimately resolved through the Interest Arbitration process in accordance with the applicable provisions of the Arbitration Procedure contained in the collective bargaining agreement. The case presents the positions of the Lancaster Police Benevolent Association (Union) and the Town of Lancaster on the open issues in the impasse. The case requires students to review the information in the case and develop an appropriate Award (Arbitration decision for the case) for each of the issues. The case represents an actual impasse that went to a formal Interest Arbitration hearing. The Interest Arbitration case is designed for use in a class in Labor Relations/Collective Bargaining or in a Human Relations class. The arbitration process is stressed as well as the difference between Rights Arbitration and Interest Arbitration.
\end{abstract}

\section{LEARNING OBJECTIVES}

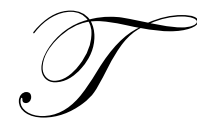

he purpose of this case is to allow students to analyze information provided at an Interest Arbitration hearing and to develop an Award for the arbitration. In addition, students have an opportunity to develop an understanding of some of the following issues including: the arbitration process, the difference between Rights Arbitration and Interest Arbitration, and factors to consider in writing an Interest Arbitration Award. Students will be required to

1. Identify key issues and determine the priority of the issues.

2. Analyze the position of each of the parties on the various issues.

3. Evaluate the criteria utilized by arbitrators in developing an Interest Arbitration Award.

4. Develop an Award that will be final and binding on the parties.

\section{INTRODUCTION}

The Town of Lancaster is situated in Erie County and covers thirty-nine (39) square miles with an approximate population of 25,000 (U.S. Census Bureau Statistics). The Village of Lancaster is located wholly within the Town. Including village residents, the total population of both Town and Village is nearly 30,000. Lancaster Police Officers have responsibility, without distinction, to both the Village and the Town.

Readers with comments or questions are encouraged to contact the author via email. 
The Town is primarily residential although several industrial parks now account for much of the Town's commercial activity. The northern and western portions of the Town have grown into busy commercial districts, while an attractive downtown area and residential neighborhoods have filled out the Village.

Lancaster is located near a major city in Western New York. The Town was founded in the early 1800s and has enjoyed considerable prosperity and affluence throughout its history. Lancaster is home to a 100 -member chorale, a symphony orchestra, and an open-air pavilion. The community is the home of several large corporations. Many of the community's largest industrial firms are located in the 120-acre Industrial Park on the Town's west side. The ten largest taxable properties have an assessed valuation in excess of $\$ 71,625,310$. Said assessed valuation from 1999 represents $9.6 \%$ of the total taxable assessed valuation for the Town.

The solid base of light industry is complemented by service businesses and financial institutions.

The New York State Electric and Gas Corporation and National Fuel Gas Distribution Corporation supply electricity and natural gas throughout the Town. The Erie County Water Authority supplies water for the Town. The Authority charges the cost for the water service against the property or property owners served. Sanitary sewer services are provided throughout the Town primarily by Town sewer districts. The respective department provides police and fire protection.

Three independently governed school districts are located wholly or partially within the Town, which rely on their own taxing powers granted by the State to raise revenues. The school districts use the Town's assessment rolls as their basis for taxation of property located within the Town.

Subject to the provisions of the State Constitution the Town operates pursuant to the Town Law, the Local Finance Law, other laws generally applicable to the Town, and any special laws generally applicable to the Town. Under such laws, there is no authority for the Town to have a charter, but pursuant to the Town Law and other laws generally applicable to home rule, the Town may from time to time adopt local laws.

The legislative power of the Town is vested in the Town Board, which consists of five members, including the Supervisor. The Supervisor is the Chief Executive Officer of the Town and is elected for a term of four years. The four other members of the Town Board are elected to four-year terms, and such terms are staggered such that two councilmen are elected every two years. All Town Board members are elected at large, and there is no limitation to the number of terms each may serve.

The Lancaster Police Benevolent Association is the sole and exclusive bargaining representative for fulltime police officers below the rank of lieutenant in the department. The unit is presently comprised of 22 officers and 2 detectives.

The Town recognizes three other bargaining units: Local 815 of the Civil Service Employee's Association representing laborers, truck drivers, and mechanics in other town departments; the Command Officers Association (ranks of lieutenant and above); and Local 1000 of the Civil Service Employee's Association, representing clerks and building department personnel.

The Town's police department patrols and polices the entire Town of Lancaster including the Village proper. Town police officers respond to all calls including first aid calls, and an enhanced 911 emergency system is in place to assure prompt response.

All sworn personnel employed by the Town's police department work what is commonly referred to as an eight-hour, 5-2 schedule. Patrol officers work a steady shift. They bid either the first shift (presently $7-3$ or $8-4$ ), the second shift (presently 3-11 or 4-12), or the third shift (Presently 11-7 or 12-8). They work five out of every seven days. 


\section{BACKGROUND OF THE DISPUTE}

The Town and the Union are parties to a Collective Bargaining Agreement effective between January 1, 1999, and December 31, 2000. Prior to the expiration of the agreement, the parties met and attempted to negotiate a successor contract. The negotiations were unsuccessful and on or about February 7, 2001, the Union filed a petition for Compulsory Interest Arbitration. The Town filed its response on February 27, 2001. On April 11, 2001, the Public Employment Relations Board designated a public arbitration panel with John G. Watson as Chairman. The Interest Arbitration hearing was held on May 31, 2001, in Lancaster, New York.

\section{RELEVANT PROVISIONS OF THE COLLECTIVE BARGAINING AGREEMENT BETWEEN THE LANCASTER POLICE BENEVOLENT ASSOCIATION AND THE TOWN OF LANCASTER}

Article 1 - Preamble

January 1, 1999 to December 31, 2000

Article 2 - Recognition

Pursuant to the certification by the New York State Public Employment Relations Board, the Town of Lancaster recognizes the Lancaster Police Benevolent Association as the sole and exclusive representative for all employees in the collective bargaining unit as set forth below.

\section{$\underline{\text { Title }}$}

(a) Police Officers

(b) Detectives

(c) Individuals occupying the rank of Lieutenant, Captain or Chief of Police are excluded from the bargaining unit.

Article 3 - Management Rights

The management of the Police Department and the direction of the working forces and the operation of the Police Force, including the hiring, promoting, and retiring of Police Officers; the suspending, discharging, or otherwise disciplining of Police Officers for just cause, any reduction or increase in the working forces, the scheduling of work, exclusive of those rights contained herein, and the control and regulation of the use of all equipment and other property of the Town, are the exclusive function of the Town Board; provided, however, that in the exercise of such functions, the Town Board shall observe the provisions of this Agreement and shall not discriminate against any Police Officer or applicant for employment because of his/her membership in or lawful activity on behalf of the Lancaster Police Benevolent Association, Inc.

Article 4 - Grievance Procedure and Arbitration

Article 5 - Outside Employment

Article 6 - Defense and Indemnification

The Town shall pay reasonable and necessary attorney's fees, disbursements, and litigation expenses, prevailing in the local legal community, incurred by an employee in his defense in a criminal proceeding in a state or federal court arising out of any act or omission that occurred or allegedly occurred, while the employee was acting or in good faith purporting to act, within the scope of his public employment. The employee in such instances shall be entitled to private counsel of his own choice, except that the Town Attorney may require that appropriate groups of employees be represented by the same private counsel. 
Article 7 - Compensation

Below is the base rates schedule adopted which governs payment of base rates during the term of this agreement.
(a) Police Officers
Effective 1/1/99
Effective 1/1/00
Starting Salary
$\$ 40,000$
$\$ 42,000$
After 1 year continuous service
43,800
45,990
46,400
48,825
After 3 years continuous service
48,300
50,715
After 4 years continuous service
51,000
53,550
(b) Detectives
Additional per year
$\$ 2,000$
$\$ 2,000$

Article 8 - Shift Differential

Any bargaining unit member working second shift $(3-11$ or $4-12)$ shall be paid $\$ 2.00$ per hour shift differential, and any unit member working third shift (11 - 7 or $12-8)$ shall be paid $\$ 3.00$ per hour shift differential.

Article 9 - Call-in Pay

If an Officer is requested to report to the Police Station for duty or ordered to report for duty other than regularly scheduled hours (except for reasons of his/her own neglect), he/she shall be paid a minimum of two (2) hours pay at the rate of time and one-half. Court appearances and training schedules will not be considered call-in, and this Section will not apply in those instances.

In lieu of call-in pay, a Police Officer shall have the option of receiving earned compensatory time.

Article 10 - Longevity

Each Police Officer in the unit covered by this Agreement shall be entitled to and will receive $\$ 300$ annually for each four (4) years of continuous service as a Police Officer. The computation of the years of service shall be based upon the date of hire and shall change on the anniversary date thereafter.

Article 11 - Overtime Pay

Overtime pay at the rate of time and one-half $\left(1 \frac{1 / 2}{2}\right)$ the regular hourly rate of pay shall be paid to Police Officers when required to continue over a tour of duty or when called back on an emergency.

Overtime shall be distributed as equitably as possible among qualified employees within the limits of practicability. Volunteers, if available, shall fill overtime vacancies. Volunteers may be denied overtime that will exceed twenty four (24) hours of overtime work in the pay period. Overtime records shall be made available to employees within their work unit at reasonable times and to Union representatives upon reasonable notice.

Article 12 - Vacations

Vacation periods with pay shall be granted to Police Officers in the unit covered by the Agreement as follows: 
After 1 year of employment

After 5 years of employment

After 10 years of employment

After 18 years of employment
2 weeks

3 weeks

4 weeks

5 weeks

Vacation time shall not be accumulated or carried over. The yearly vacation period shall commence on January 1st and end on December 31st of the same calendar year.

Police Officers shall be allowed to bid for vacation time during the last week of the calendar year where said week laps over into the ensuing calendar year.

Article 13 - Holidays

In addition to regularly scheduled days off, every Police Officer in the unit will be entitled to the following holidays with full pay:

$\begin{array}{ll}\text { a. } & \text { New Year's Day } \\ \text { b. } & \text { Lincoln's Birthday } \\ \text { c. } & \text { Washington's Birthday } \\ \text { d. } & \text { Good Friday } \\ \text { e. } & \text { Memorial Day } \\ \text { f. } & \text { Independence Day } \\ \text { g. } & \text { Labor Day } \\ \text { h. } & \text { Columbus Day } \\ \text { i. } & \text { Veterans' Day } \\ \text { j. } & \text { Thanksgiving Day } \\ \text { k. } & \text { Christmas Day } \\ \text { l. } & \text { Election Day } \\ \text { m. } & \text { Martin Luther King Day }\end{array}$

Article 14 - Health Insurance

Members shall be provided the Blue-Cross/Blue Shield plan of the Lancaster Hospital Service Corporation including Blue Million Preferred Coverage, the Full Hospital Out-Patient Rider, the threedollar generic/six dollar non-generic co-pay prescription drug rider, and the federally mandated Maternity Rider. Employees who elect the Blue Cross/Blue Shield plan shall be responsible for paying $\$ 20$ per month for a single plan or $\$ 40$ per month for a family plan. Such payment shall be made by payroll deduction in equal payments during two pay periods of each month. Alternative health care plans (HMOs) will be made available to employees, and may be substituted for Blue Cross/Blue Shield at the option of the employee. Employees who elect an HMO shall be responsible for paying \$10 per month. Such payment shall be made by payroll deduction in equal payments during two pay periods of each month.

It shall be the employee's responsibility to apply for such coverage or to make changes in existing coverage. The employer shall not be responsible to provide the coverage listed above if the employee and/or the employee's dependents are covered by any other group medical/surgical insurance plan. Members may be required to sign a statement affirming that such duplicate coverage does not exist or may be required to provide documentation of termination of other coverage.

The Town reserves the right to change insurance carriers or to become self-insured if it deems necessary. However, the Town agrees to provide at least equal benefits to the coverage contained in the Blue Cross/Blue Shield contract. "At least equal coverage benefits" shall be construed to include acceptability of coverage in the medical community. 
In the event the Town is to consider an alternative health coverage plan, the Town agrees to consult with the Union in respect to the proposed plan. If the Union does not agree that the proposed change of insurance carriers provides at least equal benefits, the parties shall enter into negotiations in respect to the equal benefits proviso in an attempt to resolve the existing differences.

Article 15 - Life Insurance

The Town shall provide twenty thousand dollars $(\$ 20,000)$ group term life insurance for every Police Officer in the unit covered by the Agreement, at no cost to the Police Officer. Police Officers shall have the option to convert to Family Whole Life Policy at the Police Officer's expense.

Article 16 - Sick Leave

A Police Officer in the unit covered by the Agreement shall earn sick time allowance for illness at the rate of one and one-half (1-1/2) days per month, which sick time shall be accumulated to a maximum of two hundred twenty (220) days.

In order to qualify for any sick leave benefit, a Police Officer who is unable to report for duty by reason of illness or physical disability shall immediately and not less than two (2) hours prior to his scheduled tour of duty, notify the Police Department of that fact and shall state the nature of his illness or disability. When the Police Officer is unable to report in his own behalf, a responsible person may make the report.

Every absence in excess of three (3) days shall be certified by a licensed physician, said certification to be presented to the Chief of Police or his designee. Prior to returning to work, after any sick leave in excess of three (3) days, the Police Officer shall present a release from a licensed physician indicating his ability to perform his required duties. In the absence of such said report, unless waived by the Chief of Police for good cause, time lost shall not be considered sick leave, and such Police Officer shall receive no benefits.

Article 18 - Personal Leave

Non-cumulative personal leave of not more than four (4) days annually, with full pay will be granted to each Police Officer in the unit covered by the Agreement for personal business not specifically covered elsewhere in this Agreement. Personal business shall be deemed to include only business of such a nature that it cannot be conducted at a time other than such Police Officer's regularly scheduled working hours.

Applications for such personal leave shall be submitted to the Chief of Police not less than three (3) days prior to the requested absence except in cases of emergency.

Article 19 - Bereavement Leave

Article 20 - Clothing Allowance

The following articles of clothing shall be furnished and issued by the Town for each uniformed Police Officer in the unit covered by the Agreement and replaced by the Town when deemed necessary by the Chief of Police:
(a) 3 winter and 3 summer shirts and patches
(b) 4 pairs trousers
(c) 1 winter jacket
(d) 1 lightweight jacket
(e) 1 raincoat 
(f) 3 ties

(g) 1 hat

Article 21 - Equipment Allowance

Article 22 - Association Rights

Article 23 - Seniority

For the purposes of the Article, seniority shall be defined as the length of an employee's uninterrupted service in title, including sick leave, military leaves not to exceed four years, and other leaves of absence which do not exceed one year and Workers' Compensation Leave.

Article 24 - Dues Deduction

The Town shall accord the Union separate deductions on its payroll for membership dues certified by the Union as authorized by the employees on a payroll deduction authorization and membership card provided by the Union for that purpose.

Effective upon execution of this Agreement, the Town shall deduct from the wages of each employee who is not a member of the Union an Agency Shop fee equivalent to the regular dues levied by the Union and to remit such Agency Shop fees to the Union.

Article 25 - No Strike No Lockout

The Union hereby affirms that it does not assert the right to strike against the Town, to assist or participate in any such strike, or to impose an obligation upon its members to conduct, assist, or participate in such a strike or concerted withholding of services.

The Town will not institute any form of lockout against employees covered by the Agreement.

Article 26 - Savings Clause

Should any article, section, or portion thereof of this Agreement be held unlawful and unenforceable by any court of competent jurisdiction, such decision shall apply only to the specific article, section, or portion thereof directly specified in the decision; upon the issuance of such a decision, the parties agree immediately to negotiate a substitute for such article, section, or portion thereof.

\section{$\underline{\text { Union Proposals }}$}

The Union submitted the following proposals at the beginning of the negotiations for the new agreement.

1. Article 7-Compensation

Effective January 1, 2001, the salary schedule for police officers is increased by $7.0 \%$. Effective January 1, 2002 , the salary schedule for police officers is increased by $7.0 \%$. Detective's pay scale is adjusted to $5.0 \%$ over top patrolman.

2. Article 10 - Longevity

Effective January 1, 2001, each officer shall receive $\$ 350$ for each step of continuous service. Effective January 1, 2002, each officer shall receive $\$ 400$ for each step of continuous service. Steps shall be established at three-year intervals of continuous service. 
3. Article 12 - Vacations

Effective January 1, 2001, vacation increments are changed to 1 year, 5 years, 10 years, 15 years. After 15 years, an additional vacation day added per each year of service.

4. Article 13 - Holidays

Effective January 1, 2001, addition of Christmas Eve to list of holidays. Effective January 1, 2002, addition of New Year's Eve to list of holidays.

5. Article $14-$ Health Insurance

Effective January 1, 2001, the Town pays for full coverage of single and family plans, and the Town will provide additional coverage of: $\$ 2$ generic/ $\$ 4$ non-generic prescription co-pay, preventative care of newborns, maximum psychiatric care and maximum chiropractic care.

Effective January 1, 2001, the Town will provide a dental plan to all officers and their families.

Effective January 1, 2001, the Town will implement a vision care plan to all officers and their families.

Effective January 1, 2001, all medical insurance benefits shall be provided to any officer's surviving spouse.

6. Article 15 - Life Insurance

Effective January 1, 2001,life insurance coverage will increase to $\$ 30,000$ for every Police Officer.

7. Article 16 - Sick Leave

Effective January 1, 2001, all officers shall earn sick time at a rate of two days per month.

Effective January 1, 2001, sick time may be accumulated to 250 days, plus 20 days for every year thereafter.

Effective January 1, 2001,all officers shall be granted up to 40 hours of paid sick leave per year to care for family members.

Effective January 1, 2001, at retirement all officers will receive $75 \%$ of accumulated sick leave. Remaining $25 \%$ will be applied to supplemental medical coverage after age 65 . All benefits of this section are provided to surviving spouse.

Effective January 1, 2001, a sick bank is to be created to aid police officers whose sick leave is exhausted.

8. Article 18 - Personal Leave

Effective January 1, 2001, the Association shall be allotted five days personal leave annually.

9. $\quad$ Article 20 - Clothing Allowance

Effective January 1, 2001, the Town will increase the supplemental uniform allowance to $\$ 625$. Effective January 1, 2002, increase to $\$ 725$. 


\section{$\underline{\text { Town Proposals }}$}

The Town submitted the following proposals at the beginning of the negotiations for the new agreement.

1. Article 3 - Management Rights

The Town would amend the present management rights clause: eliminate the just cause standard, the rights to union representation and eliminate the discrimination provision.

2. Article 10 - Longevity

The Town proposes a maximum cap on longevity payments of $\$ 2,000$ for any officer in a given year.

3. Article 10 - Vacations

The Town proposes to reduce the number of vacation weeks that may be taken in single day increments from two weeks to one week.

4. Article $14-$ Health Insurance

The Town proposes to select its health insurance plan each year, to increase deductibles (no monetary amount specified), and to increase contribution for health insurance to $\$ 60$ per month for family premium coverage and $\$ 30$ per month for single premium coverage.

\section{Other Relevant Information Provided By the Parties}

\section{Comparable Communities}

The parties agreed upon the following communities for making comparisons: Town of Akron, Town of Allport, Town of Bloomfield, Town of Chester, Town of Columbia, Town of Lansing, Town of Evans, and Town of Lockport.

These towns provide the most appropriate comparability because of their similar budgeting and taxing processes. The major source of income for each town listed, as well as the Town of Lancaster, is real property taxes. Since the amount and the ratio of real property tax assessed to residents in Erie County is established by the County, comparisons with other communities is illogical and ineffective.

\section{Compensation}

Table 1 below shows relevant police salary increases for the last several years. It should be noted a few police associations are in the process of negotiations for a new agreement or have declared an impasse and are in the process of Interest Arbitration.

Lancaster Police Officers are required to live within the Town boundaries for the first twelve years of their employment. Lancaster is a fairly affluent community; the cost of a home is much greater than in the surrounding municipalities.

Since property values are higher in Lancaster, police officers pay commensurately higher property taxes than their fellow officers in comparable communities.

As a result of the high cost of housing and high taxes, a significant number of Lancaster Police Officers report that they are engaged in some form of outside employment. In addition, many police officers have working spouses. A survey of Lancaster Police Officers revealed that nearly one-half of them supplement their full-time police jobs 
with other employment. Sixteen of twenty-one officers who responded to the survey indicate that their spouses either work full time or part time.

Table 1

\section{POLICE SALARY INCREASES}

\begin{tabular}{lllllllll} 
& $\mathbf{1 9 9 5}$ & $\mathbf{1 9 9 6}$ & $\mathbf{1 9 9 7}$ & $\mathbf{1 9 9 8}$ & $\mathbf{1 9 9 9}$ & $\mathbf{2 0 0 0}$ & $\mathbf{2 0 0 1}$ & $\mathbf{2 0 0 2}$ \\
Akron & $5.0 \%$ & $3.0 \%$ & $5.0 \%$ & $3.0 \%$ & $4.0 \%$ & $4.0 \%$ & \multicolumn{2}{l}{ have not settled new contract } \\
Allport & $6.0 \%$ & $6.0 \%$ & $6.0 \%$ & $3.0 \%$ & $4.0 \%$ & $4.0 \%$ & $4.5 \%$ & $4.5 \%$ \\
Bloomfield & $5.5 \%$ & $5.0 \%$ & $5.0 \%$ & $3.5 \%$ & $4.5 \%$ & $4.5 \%$ & have not settled new contract \\
Chester & $5.5 \%$ & $5.5 \%$ & $5.0 \%$ & $5.0 \%$ & $4.0 \%$ & $4.0 \%$ & $4.0 \%$ & $4.0 \%$ \\
Columbia & $5.5 \%$ & $5.5 \%$ & $4.25 \%$ & $2.0 \%$ & $4.5 \%$ & $4.0 \%$ & $4.0 \%$ & $4.0 \%$ \\
Lansing & $5.0 \%$ & $5.0 \%$ & $3.0 \%$ & $1.0 \%$ & $4.0 \%$ & $3.8 \%$ & $4.5 \%$ & $4.0 \%$ \\
Evans & $6.0 \%$ & $5.25 \%$ & $4.0 \%$ & $4.0 \%$ & $4.0 \%$ & $4.25 \%$ & $4.25 \%$ & $4.5 \%$ \\
Lockport & $7.0 \%$ & $7.0 \%$ & $5.0 \%$ & $5.0 \%$ & $3.9 \%$ & $4.0 \%$ & have not settled new contract \\
Lancaster & $5.0 \%$ & $5.5 \%$ & $5.75 \%$ & $4.0 \%$ & $4.5 \%$ & $5.0 \%$ & have not settled new contract
\end{tabular}

The Union proposed that the pay scale for detectives be set at 5.0\% above the pay rate of the highest paid patrolman. Wage compression among the ranks can be a significant problem and can blur the lines between separate and distinct positions. A promotion needs to have some meaning beyond the rank and duties of the higher position. A detective in the department must be paid a wage commensurate with the higher title, and with a significant enough wage differential to manifest this distinction.

A comparison of detective wages in surrounding Towns reveals that the Lancaster Police Department is the only department that does not maintain an adequate differential between the ranks.

The Union proposed to increase longevity payments from $\$ 300$ annually for each four (4) years of continuous service to payments of $\$ 350$, beginning in 2001, for each three (3) years of continuous service, and payments of $\$ 400$, beginning in 2002 , for each three years of continuous service. For its part, the Town seeks to cap the amount of longevity pay for the Town's most senior officers.

\section{Vacations}

The Union proposed a modification to the present vacation schedule, which would lower the years of employment to qualify for five weeks' vacation from eighteen (18) years to fifteen (15) years. In addition, the Union proposal would credit an officer with one additional vacation day for each year worked after fifteen years.

The fifteen-year/five week benefit is largely available in other comparable departments in Erie County. The towns of Akron, Chester, and Columbia presently provide their officers with five weeks' vacation after fifteen years of service, and one town, Lansing, provides this benefit after ten years of service. Other departments who do not provide this benefit do not require that their officers work as many days or hours per year as Lancaster police officers.

\section{Dental Plan}

No cost information was provided relative to this proposal 


\section{Vision Plan}

The Union proposed the Town provide a vision care plan at no cost to the officer or his/her family. The yearly cost to the Town would be approximately $\$ 4,400$.

\section{Surviving Spouse (Medical Insurance)}

The Union proposed that all medical insurance benefits provided be made available to any officer's surviving spouse. Presently, the Town provides health insurance to an officer or his or her surviving spouse by applying accumulated sick time toward health insurance premiums at age 65. Retired officers, before reaching age 65 , are entitled to receive single or family health insurance coverage at the same benefit level as members of the police force. Nowhere in the contract is there a provision for health insurance for a surviving spouse in the event that an officer dies prior to age 65 . In fact, a surviving spouse is only entitled to the benefit of his or her spouse's sick leave days, which are applied toward medical insurance premiums, after the age of 65 .

\section{Sick Leave Accumulation}

No other town earns sick leave at the amount of two days per month.

\section{Sick Time Redemption}

The Union proposed that $75 \%$ of an officer's accumulated sick time shall be compensated at the time of his or her retirement. The value of the remaining sick leave (25\%) is to be applied toward supplemental medical coverage for the officer after reaching the age of 65 . The benefits proposed are also to be provided to the surviving spouse of any police officer or retired police officer. All of the other Towns have sick leave redemption provisions in their collective bargaining agreements.

\section{Clothing Allowance}

The Union proposal represents a modest figure in comparison with other comparable departments. The Town of Akron provides a $\$ 1,300$ uniform maintenance allowance. The Town of Bloomfield provides a $\$ 1,025$ uniform allowance. The Town of Columbia pays for its officers' uniforms while also providing a $\$ 675$ annual cleaning allowance. The Town of Evans provides a uniform allowance of $\$ 925$ per year. Only the Town of Lansing provides a lesser benefit than the Town of Lancaster.

\section{$\underline{\text { Ability to Pay }}$}

In an official statement accompanying the Lancaster Comprehensive Annual Financial Report for the fiscal year ended December 31, 1999, Town Supervisor Dennis J. Orsini painted a very healthy picture of the Town's financial condition. Orsini noted that the Town's assessment base had grown steadily over the past ten years and that in 1999 there were 115 building permits issued for single family homes. The report also noted that:

plans are being completed for the development of a 144-acre office-industrial-research and development park. The area, to be known as the Lancaster Commerce Center, will be geared to high technology and aerospace companies.

Regionally, the western part of New York State has benefited or is hopeful to benefit in the future from:

- $\quad$ The free trade agreement with Canada. With its strategic location near the center of Canadian commerce, industry and population of Western New York has been a beneficiary of business investment and job creation. 
- Lake Erie waterfront development is seen as a major untapped resource. A Horizons Waterfront Commission has been established and funded to develop a comprehensive waterfront master plan to guide, promote, and undertake new waterfront development in cooperation with local agencies.

The report also announced a major initiative in 1999 and for the future. In announcing the most significant revenue increases in the year, Supervisor Orsini pointed to increased sales tax receipts from Erie County and increased real property tax receipts due to an increased assessment base. Orsini indicated that the "use of money" increased due to the Town taking advantage of higher interest rates at which it invested its increased surplus.

The Town's audited financial statements confirm that the Town has experienced continued growth in its overall revenue base over the three-year period reviewed. The Town's tax base, the total assessed valuation, increased by $\$ 15.6$ million, or $1.5 \%$, in 1999 to $\$ 1.066$ billion. Financial figures derived from the Town's General Fund are indicative of a very healthy undesignated fund balance.

\section{TEACHING NOTES}

What is the difference between Rights Arbitration and Interest Arbitration?

Arbitration is a process whereby the parties to a dispute select an impartial third party who, based upon the merits of the case, presents a final and binding award to the parties. The Arbitrator acts as a judge and jury. There are two types of union-management disputes: rights disputes and interests disputes.

\section{Rights Arbitration}

Disputes over the interpretation and application of the various provisions of an existing contract are submitted to Rights Arbitration. This is the most common type of arbitration and is used in settling grievances.

\section{Interest Arbitration}

This type of arbitration involves disputes over the terms of proposed collective bargaining agreements. Interest Arbitration is most frequently used in the public sector where governmental jurisdictions prohibit their employees from striking. While there is no uniform application of this method, numerous states have legislation permitting the use of Interest Arbitration to settle unresolved issues for public employees.

\section{Public Sector}

Numerous states have enacted legislation covering public sector employees. As an example, in New York State the Taylor Law was enacted in 1967 to promote harmonious and cooperative relationships between government and its employees and to protect the public by assuring the orderly and uninterrupted functions of government. The Taylor Law, as well as other laws passed in other states, provides for the handling of impasses between the government agency and the representative union. Since public employees are not permitted to strike, the typical legislation in the various states would provide for mechanisms between the parties that would allow them to reach an agreement in contract negotiations without striking. For police and fire bargaining units, it is essential that individuals in these bargaining units reach an agreement without the threat of a strike. The typical process, therefore, would involve mediation after an impasse has been declared, and Interest Arbitration if the impasse cannot be resolved through mediation.

\section{The Taylor Law Interest Arbitration standards: Statutory Structure and Criteria}

What criteria are used by an arbitrator in an Interest Arbitration Hearing? Arbitration.

In New York State, the Taylor Law provides the following procedure to be followed in an Interest 
Interest Arbitration proceedings are initiated when the Public Employment Relations Board (hereinafter PERB), upon the petition of either party, refers the impasse between them to a Public Arbitration Panel. The panel consists of three individuals: one member recommended by the Town; one member recommended by the Union; and an arbitrator mutually selected by the parties from a list provided by PERB. The panel is required to hold hearings on "all matters related to the dispute," (Civil Service Law Section 209.4(c)(iii)), and "all matters presented to the public arbitration panel . . . shall be decided by a majority vote of the members of the panel." (Section 2094(c)(iv)).

The panel is directed to "make a just and reasonable determination of the matters in dispute." (Section 209.4(c)(v)). The statute identifies the following criteria as relevant to the Board's inquiry and determinations:

In arriving at such determination, the panel shall specify the basis for its findings, taking into consideration, in addition to any other relevant factors, the following:

a. Comparison of the wages, hours, and conditions of employment of the employees involved in the arbitration proceedings with wages, hours, and conditions of employment of other employees performing similar services or requiring similar skills under similar working conditions and with other employees generally in the public and private employment in comparable communities;

b. The interest and welfare of the public and the financial ability of the public employer to pay;

c. Comparison of the peculiarities in regard to other trades or professions, including specifically:

(1) hazards of employment

(2) physical qualifications

(3) education qualifications

(4) mental qualification

(5) job training and skills

d. The terms of the Collective Bargaining Agreement negotiated between the parties in the past providing for compensation and fringe benefits, including, but not limited to, the provisions for salary, insurance and retirement benefits, medical and hospitalization, time off and job security.

The Panel's determination is "final and binding upon the parties for the period prescribed by the panel, but in no event shall such period exceed two years from the termination date of the previous Agreement." (Section 209.4(c)(vi)). The determination "shall not be subject to the approval of any local legislative body or other municipal authority. However, it is subject to judicial review in a manner prescribed by law." (Section 209.4(c)(vii)).

\section{Elkouri and Elkouri}

According to Elkouiri and Elkouri, How Arbitration Works, $5^{\text {th }}$ ed., Chapter 18, Standards in Arbitration of Interest Disputes, a number of factors are considered by the Arbitrator when rendering an Interest Arbitration award. Some of those factors include the following:

1. Prevailing practice-"Without question the most extensively used standard in Interest Arbitration is prevailing practice. This standard is applied in most interest cases. The result is that disputants indirectly adopt the results of the successful collective bargaining of other parties similarly situated. The arbitrator relies upon precedent, adopting that which has been adopted by other parties through collective bargaining or as a result of arbitration awards."

2. Comparability - "A comparison of the issues between the parties such as wages, hours, and conditions of employment of employees involved in the arbitration proceedings with those of other employees performing 
similar services in comparable communities. Comparability might include such factors as proximity, population, size of the police or fire force, and size of the budget."

Other factors to consider include cost of living, living wage, and ability to pay. In the public sector the employer often does not have sources of revenue apart from taxing power.

\section{AWARD}

Holidays

It is the opinion of the Panel that there be no change in the number of holidays in the new agreement. This fact is predominantly based on the number of holidays currently being received by comparable towns.

$\underline{\text { Dental Plans }}$

It is the opinion of the Panel the proposed plan should not be added to the agreement.

$\underline{\text { Vision Plan }}$

The Panel feels the Union has not submitted compelling evidence to support its view that this proposal be added to the new agreement.

Surviving Spouse (Medical Insurance)

The Panel is of the opinion this proposal should not be added to the new agreement.

$\underline{\text { Sick Leave Accumulation }}$

It is the opinion of the Panel this proposal should not be added to the new agreement as a comparison of other towns shows that none of the other departments have two days per month of sick time. Furthermore, the 220 days maximum accumulation appears to be more than appropriate compared to the other towns in the area.

\section{Family Sick Leave}

It is the opinion of the Panel this proposal should not be added to the new agreement.

\section{$\underline{\text { Sick Leave Bank }}$}

It is the opinion of the Panel this proposal should not be added to the new agreement.

\section{$\underline{\text { Clothing Allowance }}$}

It is the opinion of the Panel that an increase is warranted. Accordingly, it is recommended the Clothing Allowance be increased to $\$ 625$ in 2001 and to $\$ 725$ in 2002.

\section{$\underline{\text { Sick Leave Redemption }}$}

It is the opinion of the Panel that the Sick Leave Redemption proposal be added to the new agreement in a very modest fashion. In reviewing the comparable data, there is no question that other towns cited by the Union have included Sick Leave Redemption in their contracts. Furthermore, the information submitted by the parties concerning the ability to pay shows that the Town is in a very favorable position financially. While the Panel is sympathetic to the position of the Town that this is a new and costly proposal, notwithstanding this fact, other 
municipalities have capitulated to police bargaining units relative to this issue. Accordingly, Lancaster Police Officers should receive twenty-five (25) percent of their accumulated sick time to be compensated at the time of his or her retirement. The value of the remaining sick leave $(75$ percent) is to be applied toward supplemental medical coverage for the officer after reaching the age of 65 .

$\underline{\text { Vacations }}$ agreement.

It is the opinion of the Panel that no change be made in the vacation section of the contract in the new

\section{Compensation}

It is the opinion of the Panel that the Police Officers should receive a four and a half percent (4.5) salary increase effective January 1, 2001, and a four and a half (4.5) percent salary increase effective January 1, 2002. Furthermore, it is the opinion of the Panel that the Detectives should receive salary at a rate of five (5) percent above the highest-paid officer in the bargaining unit.

\section{Longevity}

It is the opinion of the Panel the following Longevity Payments provision for Police Officers be added to the new agreement.

Each Police Officer in the unit covered by this Agreement shall be entitled to and will receive longevity payments according to the following schedule:

\begin{tabular}{|lrr|}
\hline $\begin{array}{l}\text { Years of } \\
\text { Continuous } \\
\text { Service }\end{array}$ & $\underline{2001}$ & $\underline{2002}$ \\
4 & & \\
4 & 350 & 400 \\
8 & 650 & 700 \\
12 & 950 & 1,000 \\
16 & 1,250 & 1,300 \\
20 & 1,550 & 1,600 \\
24 & 1,850 & 1,900 \\
28 & 2,150 & 2,200 \\
& & \\
\hline
\end{tabular}

The computation of the years of service shall be based upon the date of hire and shall change on the anniversary date thereafter. There shall be seven (7) steps in the schedule, and the maximum longevity payment shall be capped at $\$ 2,200$. Should any Police Officer as of January 1, 2001, receive a longevity payment greater than $\$ 2,150$, such officer shall continue to receive the greater longevity payment.

\section{Medical Coverage}

It is the opinion of the Panel no changes be made in the medical coverage in the new agreement.

Management Rights

It is the opinion of the Panel no changes be made in the Management Rights in the new agreement.

\section{BIBLIOGRAPHY}

1. Elkouri \& Elkouri, How Arbitration Works, Fifth Edition, 1997, The Bureau of National Affairs, Inc.

2. The Taylor Law, New York State Public Employment Relations Board.

3. Mondy, Noe, \& Premeaux, Human Resource Management, Eighth Edition, 2002, Prentice Hall.

4. $\quad$ Brief filed by the Town of Lancaster (name changed).

5. Brief filed by Lancaster Police Benevolent Association.

6. Labor Agreement between the Town of Lancaster and the Lancaster Police Benevolent Association.

7. Notes taken by the Arbitrator at Interest Arbitration hearing held between Town of Lancaster and Lancaster Police Benevolent Association. 
Notes 